\title{
The Significance of Shed Membrane Particles during Programmed Cell Death In Vitro, and In Vivo, in HIV-1 Infection
}

\author{
Karine Aupeix, ${ }^{\star}$ Bénédicte Hugel,, ${ }^{*}$ Thierry Martin, ${ }^{\star}$ Pierre Bischoff, ${ }^{\star}$ Helmut Lill,‡ Jean-Louis Pasquali, ${ }^{\star}$ \\ and Jean-Marie Freyssinet ${ }^{\star \S}$ \\ *Institut d'Hématologie et d'Immunologie, Faculté de Médecine, Université Louis Pasteur, 67085 Strasbourg, France; ${ }^{\ddagger}$. \& D. New \\ Diagnostics, Immunology, Boehringer Mannheim GmbH, 182327 Tutzing, Germany; and ${ }^{\S}$ Unité 143 Institut National de la Santé et de la \\ Recherche Médicale, Hôpital de Bicêtre, 94275 Le Kremlin-Bicêtre, France
}

\begin{abstract}
The plasma membrane remodeling, including the early transverse redistribution of phosphatidylserine, is a general feature occurring in cells in which a death program has been induced. In most cases, studies of this kind have focused mainly on cells. In this study, we report a clear correlation between the degree of apoptosis induced by a variety of agents in several types of cultured cells and the amount of shed membrane microparticles captured in the corresponding supernatants by insolubilized annexin $\mathrm{V}$, a protein showing a strong affinity for phosphatidylserine. Such particles carry membrane antigens specific of the cells they stem from, and through which capture is also feasible. Homologous circulating microparticles were captured in peripheral blood from individuals with HIV-1 infection. A substantial proportion bore CD4 antigen. In some cases, $\mathrm{CD}^{+}$particles could be detected even in the absence of circulating CD4 ${ }^{+} \mathrm{T}$ cells, testifying to the presence of such resident cells in lymphoid tissues. These results suggest that shed membrane particles are one of the hallmarks of programmed cell death, of particular interest when the corresponding cells are hardly accessible. (J. Clin. Invest. 1997. 99:1546-1554.) Key words: apoptosis • phosphatidylserine • membrane shedding $\bullet$ microparticles $\bullet$ particle capture
\end{abstract}

\section{Introduction}

Programmed cell death, or apoptosis, is a regulated process of fundamental significance in the maintenance of homeostasis in multicellular organisms. Hence, it is obvious that a variety of disorders are associated with an excess of cell death or increased cell survival. Apoptosis is accompanied by characteristic changes of the cell morphology among which shrinkage, membrane blebbing, and nucleus condensation are the most frequently evoked (1). Budding and disintegration by frag-

The first two authors contributed equally to this work.

Address correspondence to Jean-Marie Freyssinet, Institut d'Hématologie et d'Immunologie, Faculté de Médecine, 4, rue Kirschleger, 67085 Strasbourg, France. Phone: +33-(0)-3-88-36-62-42 or +33-(0)-3-88-24-33-39; FAX: +33-(0)-3-88-25-58-83; E-mail: jean-marie. freyssinet@hemato-ulp.u-strasbg.fr

Received for publication 9 September 1996 and accepted in revised form 16 January 1997.

J. Clin. Invest.

(C) The American Society for Clinical Investigation, Inc.

0021-9738/97/04/1546/09 \$2.00

Volume 99, Number 7, April 1997, 1546-1554 mentation in multiple bodies is the ultimate stage of this death process (2). Early transverse redistribution of plasma membrane phosphatidylserine is another ubiquitous feature of cells undergoing apoptosis independently of the triggering signal (3). This aminophospholipid is almost entirely sequestered in the plasma membrane inner leaflet of non-stimulated cells (4). When exposed, phosphatidylserine becomes a determinant for phagocyte recognition of cells to be cleared (5-8). This elimination pathway, involving several possible receptors (9), is believed to be highly efficient, explaining why apoptotic cells are hardly detectable in vivo.

Most of the studies have focused on cells, and recent observations stress that phosphatidylserine exposure could have an impact in the development of procoagulant and/or immune responses (10-13). However, phosphatidylserine-dependent procoagulant activities have been detected in the supernatant of THP-1 monocytic cells in which apoptosis had been induced (13). On a functional basis, these membrane-associated activities were not different from those of (micro)particles derived from the plasma membrane of endotoxin-stimulated monocytes (14) or ionophore-activated Epstein-Barr virus-infected B lymphocytes $(15,16)$. This prompted us to search for a possible relationship between the degree of apoptosis in cultured cells and the shedding of particles probably stemming from surface blebs. The high affinity of annexin $\mathrm{V}$ for phosphatidylserine (17) enabled the capture of such particles and the estimation of the amount with respect to their procoagulant phospholipid content. Because a clear correlation was evidenced, this approach was used to assess the presence of circulating particles in vivo which could reflect ongoing apoptosis. HIV infection is one of the situations where programmed cell death is thought to occur at a high degree, although the mechanism of activation by viruses has not yet been elucidated $(1,18$, 19). The loss of circulating $\mathrm{CD} 4^{+} \mathrm{T}$ cells is the hallmark of in vivo HIV infection, and it is, of course, tempting to incriminate apoptosis. Despite the lack of evidence that HIV activates the death program in cells it infects (19), it can be assumed that circulating $\mathrm{CD}^{+}$apoptotic particles are of particular significance, especially in a context where $98 \%$ of the cells reside in the lymphoid tissues and the $2 \%$ which circulate may disappear. This is why this part of the study was carried out in peripheral blood samples from HIV-1-infected individuals.

\section{Methods}

Materials. Cell culture reagents were from Life Technologies (European Division, Paisley, UK), except X-VIVO 15, which was from BioWhittaker (Walkersville, MD). mAbs to CD4, CD11a, CD18, as well as control $\mathrm{IgG} 1$, all conjugated with FITC were from Immunotech (Marseilles, France). Biotinylated mAbs to CD4, CD11a, CD14, irrelevant biotinylated $\mathrm{IgGs}$, and nonconjugated $\mathrm{mAb}$ to $\mathrm{CD} 4$ were from 
Leinco Technologies (Ballwin, MO). The mAb to human platelet glycoprotein Ib (GP Ib) was a kind gift from Dr. F. Lanza (Unité 311 INSERM, Strasbourg, France). Human blood coagulation factors were the same as those used in a recent study reported by our group (13). Factor V was a product from Diagnostica Stago (Asnières, France). Natural annexin $\mathrm{V}$ was purified from human placenta and characterized according to a previous report (20). Recombinant human annexin $\mathrm{V}$ was purchased from Bender MedSystems (Vienna, Austria). High binding capacity streptavidin-coated microtitration plates, $1-O-n$-octyl$\beta$-D-glucopyranoside, biotin-X-OSu, Chromozym TH, and mAb to CD4 were from Boehringer Mannheim (Mannheim, Germany). Actinomycin D, cycloheximide, etoposide, $7 \beta$-hydroxycholesterol $(7 \beta-\mathrm{OH}),{ }^{1}$ 25-hydroxycholesterol (25-OH), propidium iodide (PI), phosphatidylcholine and phosphatidylserine from bovine brain, type I-A RNAse A, and HSA were products from Sigma Chemical Co. (St. Louis, MO). Recombinant human TNF- $\alpha$ was from Genzyme Corp. (Cambridge, MA). D-phenylalanyl-prolyl-arginyl chloromethyl ketone (PPACK) and 1,5-dansyl-glutamyl-glycyl-arginyl chloromethyl ketone (Dns-GGACK) were obtained from Calbiochem Corp. (San Diego, CA). All other reagents were of the highest available purity grade.

Cell culture. Myeloid U-937 and HL-60 were cultured in RPMI 1640 medium with glutamax-I and phenol red, supplemented with nonessential amino acids, sodium pyruvate $(1 \mathrm{mM})$, gentamycin, and $10 \%$ heat inactivated $\mathrm{FCS}$ at $37^{\circ} \mathrm{C}$ in humidified $5 \% \mathrm{CO}_{2}$ atmosphere. Monocytic THP-1 cells were cultured in the above medium supplemented with $2 \mu \mathrm{M} \beta$-mercaptoethanol. Lymphoid CEM T cells were cultured in X-VIVO 15 medium. Cell counts were determined using a hemocytometer.

Induction of apoptosis. Cells were seeded at $3 \times 10^{5}$ cells per ml $6 \mathrm{~h}$ before treatment. Oxysterols (OS) were dissolved in ethanol at $10^{-2} \mathrm{M}$ and added to culture medium at final concentrations indicated in Results. For each experiment, a control was performed in which the ethanol concentration was the same as that contributed by OS addition. Other apoptosis inducing agents were added from aqueous stock solutions at concentrations indicated in Results. THP-1 treatments for the assay of procoagulant activities in the supernatant were performed exactly as described in reference 13 except culture medium did not contain FCS and phenol red.

Cell labeling and flow cytometry analysis. Cells were numbered, and $1 \times 10^{6}$ were collected and washed twice with HBSS containing $1 \%$ (wt/vol) BSA. The mAbs were then added to each sample according to manufacturer's instructions and the solutions were incubated $30 \mathrm{~min}$ in the dark at $4^{\circ} \mathrm{C}$. The cells were washed twice in HBSS and were immediately analyzed by flow cytometry using a FACScan ${ }^{\circledR}$ flow cytometer (Becton Dickinson, San Jose, CA). The sheath fluid was Isoton II balanced electrolyte solution (Coulter, Krefeld, Germany). Data acquisition and analysis were conducted with Lysis II software. For each cell sample, a total of $10^{4}$ events was analyzed. Data are expressed according to the ratio (MFIsS-MFISC)/(MFICSMFICC), where MFIss is the mean fluorescence intensity (MFI) recorded when the treated sample was in the presence of specific mAb, MFIsC when in the presence of irrelevant mAb, MFICs that of untreated, i.e., control sample in the presence of specific $\mathrm{mAb}$, and MFICC when in the presence of irrelevant $\mathrm{mAb}$.

Procoagulant activities in the supernatant of oxysterol-treated THP-1 cells. After a $24 \mathrm{~h}$ incubation with oxysterols, supernatants were separated from cells by centrifugation at $600 \mathrm{~g}$. Tissue factor and prothrombinase activities were measured in $100 \mu \mathrm{l}$ of each supernatant exactly as described in reference 13.

Determination of hypodiploid DNA. After the different treatments, cells were harvested and numbered. Concentration was adjusted to $10^{6}$ cells per $\mathrm{ml}$ of $70 \%$ ethanol and fixation was allowed to proceed

1. Abbreviations used in this paper: $7 \beta-\mathrm{OH}, 7 \beta$-hydroxycholesterol; 25-OH, 25-hydroxycholesterol; annexin $\mathrm{V}^{\mathrm{Bi}}$, biotinylated annexin $\mathrm{V}$; OS, oxysterol(s). during at least $1 \mathrm{~h}$ at $4^{\circ} \mathrm{C}$. The cells were then washed once in PBS before resuspension in a solution containing type I-A RNAse A in PBS $(0.5 \mathrm{mg} / \mathrm{ml})$ and were incubated $15 \mathrm{~min}$ at $37^{\circ} \mathrm{C}$. Propidium iodide was next added at a final concentration of $10 \mu \mathrm{g} / \mathrm{ml}$ before flow cytometry analysis. Samples were allowed to stand another $15 \mathrm{~min}$ in the dark at room temperature.

Preparation of cell culture supernatants and platelet-free plasma samples. Cell supernatants were obtained by centrifugation during 10 min at $600 \mathrm{~g}$. The $\mathrm{CaCl}_{2}$ concentration was adjusted to $10 \mathrm{mM}$ just before addition in wells of the titration plate. Blood samples, $5 \mathrm{ml}$, were collected from informed and consenting healthy volunteers and HIV1-infected individuals, by vein puncture in $0.138 \mathrm{M}$ tri-sodium citrate at a final volume ratio of 9:1. Plasma was obtained by centrifugation at $1,500 \mathrm{~g}$ for $10 \mathrm{~min}$ at room temperature. Platelet-free plasma was prepared by centrifugation of the above plasma at $12,000 \mathrm{~g}$ for $1 \mathrm{~min}$ at room temperature. Just before addition in wells of the titration plate, PPACK and Dns-GGACK, two potent irreversible inhibitors of thrombin, and factor $\mathrm{Xa}$, respectively, were added to samples at a final concentration of $10 \mu \mathrm{M}$ each. Samples were then recalcified by addition of $30 \mathrm{mM} \mathrm{CaCl}_{2}$ (final concentration, yielding $\sim 10 \mathrm{mM}$ free $\mathrm{Ca}^{2+}$ ) and were immediately layed into the wells of the microtitration plate previously coated with biotinylated annexin $\mathrm{V}$.

Biotinylation of annexin $V$ and $m A b$ to platelet GP Ib. Biotinylation of natural or recombinant annexin $V$ was achieved at a 5:1 biotin/ protein $\mathrm{M}$ ratio. Biotin-X-OSu diluted in DMSO was added to annexin $\mathrm{V}$ in $75 \mathrm{mM}$ phosphate buffer, pH 7.7, containing $200 \mathrm{mM}$ $\mathrm{NaCl}$. After $90 \mathrm{~min}$ at $25^{\circ} \mathrm{C}$, the reaction was stopped by adding lysine at a final concentration of $10 \mathrm{mM}$. Biotinylated annexin V was dialyzed overnight against $3 \times 500 \mathrm{vol}$ of $75 \mathrm{mM}$ phosphate storage buffer, $\mathrm{pH}$ 7.7, containing $200 \mathrm{mM} \mathrm{NaCl}$ and $10 \mathrm{mM}$ lysine. Natural and recombinant biotinylated annexins were indistinguishable with respect to capture ability. Biotinylated $\mathrm{mAb}$ to GP Ib was obtained by the same procedure.

Microparticle capture by immobilized annexin $V$. Biotinylated annexin $\mathrm{V}$ (annexin $\mathrm{V}^{\mathrm{Bi}}$ ) was insolubilized onto streptavidin-coated microtitration plates by contact of $100 \mu \mathrm{l} /$ well of $400 \mathrm{ng} / \mathrm{ml}$ annexin $\mathrm{V}^{\mathrm{Bi}}$ diluted in TBS-Ca ${ }^{2+}(50 \mathrm{mM}$ Tris buffer, $\mathrm{pH} 7.5$, containing $120 \mathrm{mM}$ $\mathrm{NaCl}, 2.7 \mathrm{mM} \mathrm{KCl}, 1 \mathrm{mM} \mathrm{CaCl}_{2}$ ) supplemented with $45 \mu \mathrm{M}$ HSA. Incubation was performed during $30 \mathrm{~min}$ at room temperature. The plates were then washed three times with $250 \mu \mathrm{l} /$ well of TBS-Ca ${ }^{2+}$. $200 \mu \mathrm{l} /$ well of cell supernatant or platelet-free plasma was then added and allowed to be in contact with insolubilized annexin $\mathrm{V}^{\mathrm{Bi}}$ for $30 \mathrm{~min}$ at room temperature. Plates were washed three times with TBS-Ca ${ }^{2+}$, and anionic phospholipid content was determined by prothrombinase assay as described below.

Antigenic capture and characterization of released particles. Biotinylated antibodies were insolubilized onto streptavidin-coated microtitration plates. This was performed by adding $100 \mu \mathrm{l} /$ well of each antibody solution ( 1 and $10 \mu \mathrm{g} / \mathrm{ml}$ in TBS containing $45 \mu \mathrm{M}$ HSA for cell culture supernatant and platelet-free plasma samples respectively) during $30 \mathrm{~min}$ at room temperature. The plates were then washed three times with $250 \mu \mathrm{l} \mathrm{TBS.} 200 \mu \mathrm{l} /$ well of cell culture supernatant or platelet-free plasma was added and allowed to incubate for $2 \mathrm{~h}$ at room temperature before the plates were washed three times with TBS. Microparticle detection was achieved by prothrombinase assay as described below. Background values obtained with irrelevant IgGs were subtracted from those measured with specific mAbs.

In some control experiments, nonconjugated $\mathrm{mAb}$ to $\mathrm{CD} 4$, or irrelevant $\mathrm{IgG}$, were added to platelet-free plasma from $\mathrm{HIV}-1^{+}$or normal subjects at the final concentration of $10 \mu \mathrm{g} / \mathrm{ml}$, i.e., that used for insolubilization of corresponding biotinylated antibody. Incubation was allowed to proceed for $1 \mathrm{~h}$ at room temperature before loading the samples into wells coated with insolubilized $\mathrm{mAb}$ to $\mathrm{CD} 4$ or irrelevant IgG, or annexin $\mathrm{V}$, for particle capture and estimation.

In other control experiments aiming at evaluating the proportion of circulating particles of platelet origin, the plasma samples were preincubated in wells bearing insolubilized $\mathrm{mAb}$ to GP Ib or irrelevant IgG during $2 \mathrm{~h}$ at room temperature before being loaded into 
wells with insolubilized annexin V or GP Ib or irrelevant $\mathrm{IgG}$ for the capture and estimation of remaining particles.

Prothrombinase assay for the estimation of the amount of captured cell fragments. Phosphatidylserine was measured through its ability to promote the activation of prothrombin to thrombin. In the assay the blood clotting factor concentrations have been determined to ensure that this phospholipid is the rate-limiting parameter of the reaction. Immobilized particles were incubated in a final volume of $150 \mu \mathrm{l}$ with factor $\mathrm{Xa}(11.2 \mathrm{pM})$, factor $\mathrm{V}(\mathrm{a})(33.3 \mathrm{pM})$, prothrombin (1.2 $\mu \mathrm{M})$, and $2.2 \mathrm{mM} \mathrm{CaCl}_{2}$ in TBS containing $45 \mu \mathrm{M}$ HSA. After a $2 \mathrm{~h}$ incubation at $37^{\circ} \mathrm{C}$, the reaction was stopped by addition of $5 \mathrm{mM}$ EDTA. Chromozym TH, a chromogenic substrate for thrombin, was then added at a final concentration of $300 \mu \mathrm{M}$. Linear absorbance changes were recorded at $405 \mathrm{~nm}$ using a microtitration plate reader equipped with a kinetics software. Results were expressed as nanomolar phosphatidylserine equivalent by reference to a standard curve constructed by using liposomes of defined composition. The liposomes containing $33 \%$ phosphatidylserine and $67 \%$ phosphatidylcholine $(\mathrm{mol} / \mathrm{mol})$ were prepared and observed by electron microscopy according to reference 21 . In case some samples yielded values higher than the upper limit of the linearity range $(10 \mathrm{nM})$, they were diluted and the results were expressed taking into account the dilution factor. Background values obtained in the absence of annexin $\mathrm{V}^{\mathrm{Bi}}$ or biotinylated mAbs never exceeded $0.5 \mathrm{nM}$ phosphatidylserine equivalent, even in samples with the highest particle content, and were subtracted from all the data presented in this study.

\section{Results}

Procoagulant activities in the supernatant of THP-1 cells treated with oxysterols. Analyses of the supernatant of oxysteroltreated cells revealed augmented tissue factor activity when compared to untreated cells. The increase of tissue factor activity was more pronounced with $7 \beta-\mathrm{OH}$ than with $25-\mathrm{OH}$. The variations of tissue factor activity detected in supernatant likewise that associated to cells seemed to be related to the rate of OS-induced apoptosis (13). Tissue factor is a membrane glycoprotein with procoagulant activity dependent on phosphatidylserine and phosphatidylethanolamine (22). The participation of phosphatidylserine was confirmed by a specific

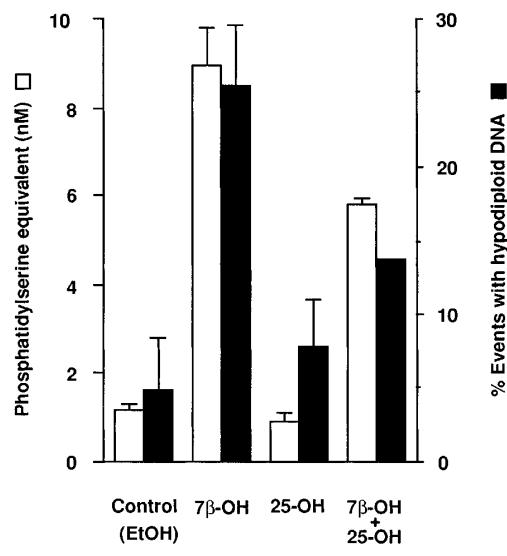

Figure 1. Comparison of the degree of oxysterol-induced apoptosis in U-937 cells and the amount of shed particles in the supernatant. The degree of apoptosis was estimated from the proportion of hypodiploid DNA. Particles were captured by insolubilized annexin $\mathrm{V}$ and their phosphatidylserine content was determined through the ability to promote the assembly of the pro-

thrombinase enzyme complex as detailed in Methods. In this assay, phosphatidylserine is the rate-limiting parameter. Cells were treated for $24 \mathrm{~h}$ with $30 \mu \mathrm{M}$ of either oxysterol, or combination of both yielding a final oxysterol concentration of $60 \mu \mathrm{M}$. The ethanol (EtOH) concentration was $0.6 \%$, i.e., that contributed by the addition of $60 \mu \mathrm{M}$ oxysterol. Values are mean $\pm \mathrm{SD}$ of six determinations (each with duplicate samples). prothrombinase assay and by annexin $\mathrm{V}$ binding (13). These observations suggested that the presence of particles in the supernatant correlated with the degree of apoptosis.

In vitro apoptosis of oxysterol-treated cells and release of particles in the supernatant. U-937 were treated for $24 \mathrm{~h}$ with each oxysterol or combination of both. Cells were recovered and stained with PI as described in Methods while supernatants were assayed for particles. Results are presented in Fig. 1. The morphological characterization of apoptotic cells and the electrophoresis analysis of extra-nuclear DNA yielded information that was identical to that reported elsewhere (23). The proportion of released particles in supernatant paralleled the degree of apoptosis evaluated at the cell level. When $7 \beta-O H$ and $25-\mathrm{OH}$ were added together, their effects were not additive. Fewer particles were measured compared to $7 \beta-\mathrm{OH}$ alone and this was reflected precisely by the proportion of cellular hypodiploid DNA. However, in HL-60 cells, the combination of the two OS resulted in additive effects (data not shown). These results show that particle shedding is not restricted to U-937 cells.

When examined by flow cytometry, particles released in the supernatant had light scatter parameters comparable to those of liposomes of mean diameter of $0.15 \mu \mathrm{m}$, with extremes at 0.03 and $0.3 \mu \mathrm{m}$ (21), or of microparticles shed from the monocyte membrane (14).

Induction of apoptosis in U-937 cells by other agents. To assess induced particle formation by agents other than OS, U-937 cells were treated with different compounds at concentration known to induce apoptosis in this cell line. TNF- $\alpha$ (24), etoposide or VP-16 (25), cycloheximide and actinomycin D (26) were used. Comparative results are presented in Fig. 2. Whatever the treatment, the amount of particles in the supernatant was proportional to hypodiploid DNA estimated in corresponding cells. Although the amplitudes were dependent on

Phosphatidylserine equivalent (nM)

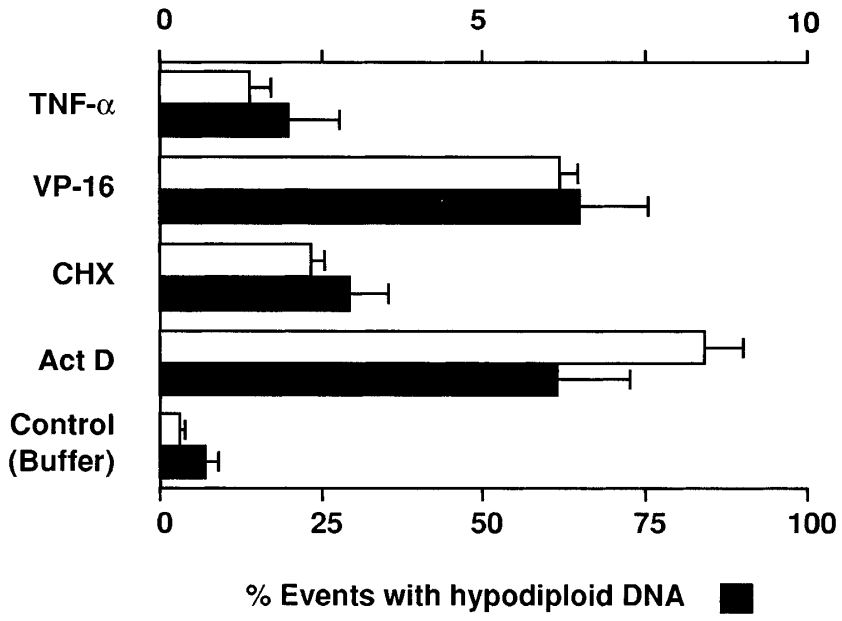

Figure 2. The parallel between the degree of apoptosis and the amount of shed particles in U-937 cells exposed to various apoptosisinducing agents. Cells were treated for $16 \mathrm{~h}$ with $100 \mu \mathrm{M} \mathrm{TNF}-\alpha$, $10 \mu \mathrm{M}$ etoposide $(V P-16), 50 \mu \mathrm{g} / \mathrm{ml}$ cycloheximide $(C H X)$, or $5 \mu \mathrm{g} / \mathrm{ml}$ actinomycin $\mathrm{D}($ Act $D)$. Determinations were performed as described in the legend of Fig. 1 and in Methods. Values are mean \pm SD of four determinations (each with duplicate samples). 


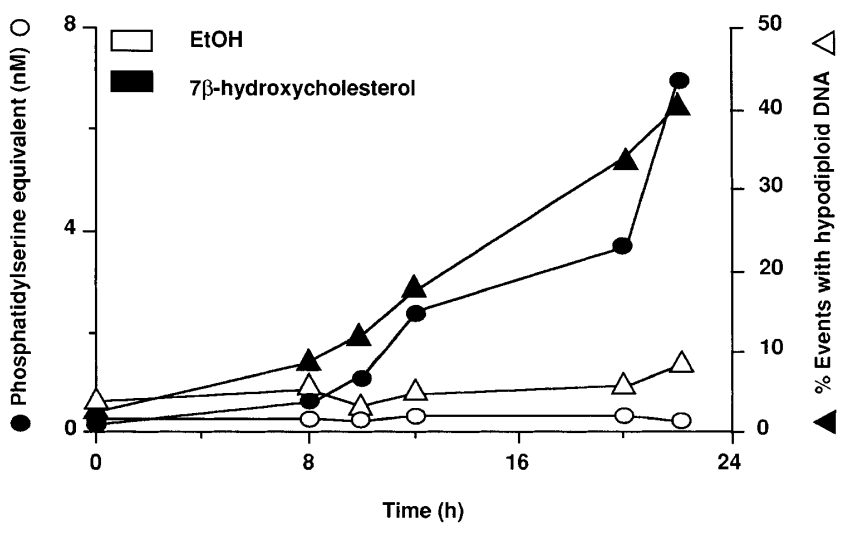

Figure 3. The time dependence of the development of apoptosis in oxysterol-treated U-937 cells and the release of particles in the supernatant. The oxysterol concentration was $30 \mu \mathrm{M}$ and that of ethanol $(\mathrm{EtOH}) 0.3 \%$. The data are from one experiment representative of three independent ones performed likewise (each with triplicate samples). The SD never exceeded $15 \%$ of each individual value determined after particle capture as described in the legend of Fig. 1 and in Methods.

the different classes of agents, this confirms that particle release is not restricted to OS and parallels DNA cleavage.

Kinetics of particle shedding and DNA fragmentation. U-937 cells were treated with either ethanol (control) or $30 \mu \mathrm{M} 7 \beta-\mathrm{OH}$ during $24 \mathrm{~h}$. At different times, cells and corresponding supernatants were harvested and analyzed for hypodiploid DNA and evaluation of vesicle proportion respectively. Results are presented in Fig. 3. After $8 \mathrm{~h}$, augmentation of hypodiploid DNA and particles was detectable. Both parameters increased almost in parallel. Comparable results were obtained with HL-60 except that the evolution was slightly more rapid (data not shown).

Correlation between hypodiploid DNA and particle shedding. Dose-response dependence of the proportion of cells with hypodiploid DNA and of the degree of particle shedding on the concentration of apoptosis inducers was studied. The proportion of cells with hypodiploid DNA is a widely used parameter for the estimation of the degree of apoptosis. The representative results shown in Fig. 4 confirm the dose-response relationships in CEM T cells and U-937 cells treated with actinomycin $\mathrm{D}$ at various concentrations during $18 \mathrm{~h}$. The degree of particle shedding closely paralleled the proportion of cells with hypodiploid DNA. These two parameters were strongly correlated with a calculated coefficient, $r$, of $\sim 0.98$ for both cell types. When $7 \beta-\mathrm{OH}$ was the inducer of apoptosis in U-937 cells, a threshold was observed at $5 \mu \mathrm{M}$ for the increase of both hypodiploid DNA and particle shedding which remained correlated with a calculated coefficient of 0.95 (data not shown). Similar results (not shown) were obtained with HL-60 cells treated by either $7 \beta-\mathrm{OH}$ or actinomycin $\mathrm{D}$, again with a threshold at $5 \mu \mathrm{M}$ for $7 \beta-\mathrm{OH}$, the correlation coefficients being 0.95 and 0.97 , respectively. As already mentioned above for Fig. 2, the amplitudes remained dependent on cell type and agent nature, but this had no effect on the correlation itself. Taken together, these results demonstrate that released particles bearing exposed phosphatidylserine are a valuable parameter for the estimation of the degree of cell apoptosis.

The fate of membrane antigens in apoptotic cells. When U-937 were treated during $16 \mathrm{~h}$ with $30 \mu \mathrm{M} 7 \beta-\mathrm{OH}$ or $25-\mathrm{OH}$ and were further analyzed by flow cytometry for the presence of membrane antigens, a clear-cut reduction of cell surfaceassociated CD4, CD11a, and CD18 was noticed in treated cells (Fig. 5). The amplitude of the decrease was related to the na-
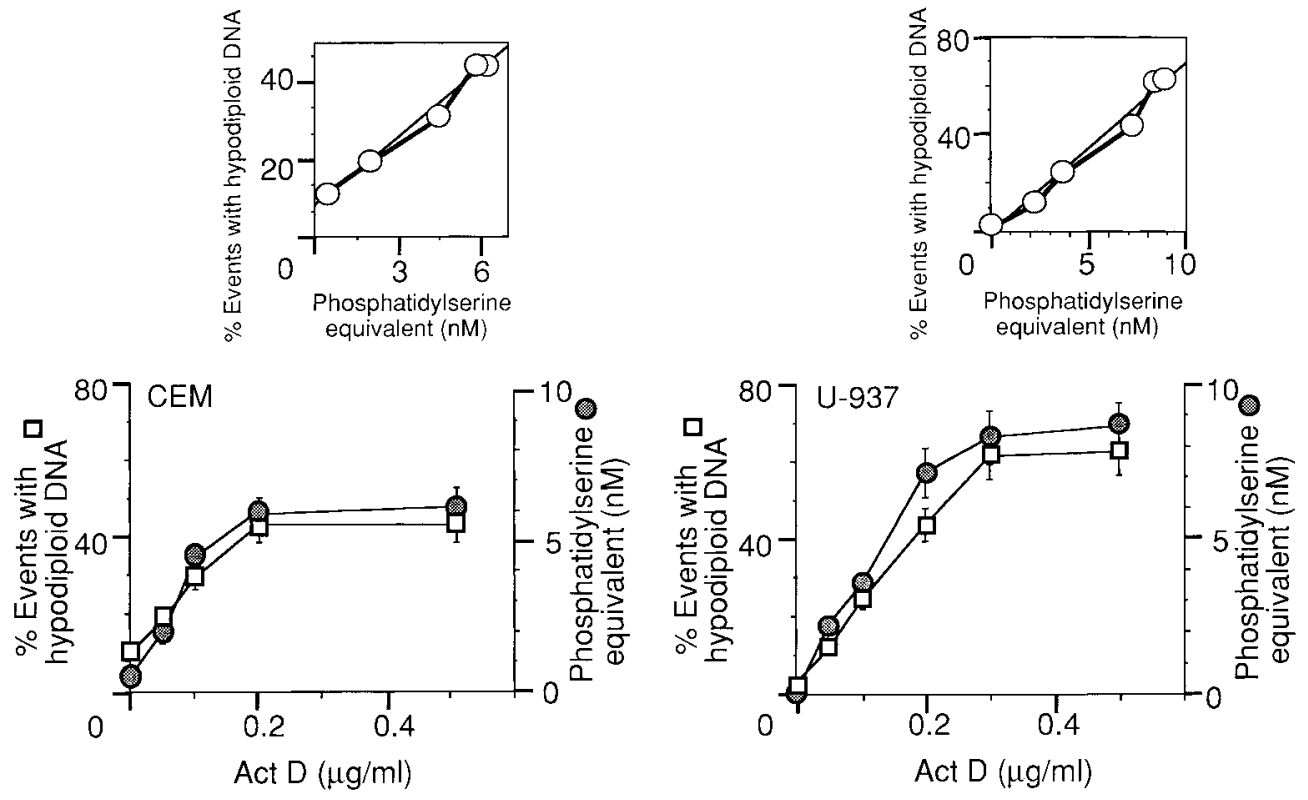

Figure 4. Correlation between the proportion of cells with hypodiploid DNA and the degree of particle shedding in apoptotic cells. (Lower curves) The doseresponse dependence of the proportion of cells with hypodipoid DNA and of the degree of particle shedding on the concentration of actinomycin D was assessed in CEM T cells and U-937 cells after 18 treatments. Determinations were performed as described in Fig. 1 and in Methods. Values are mean \pm SD of four determinations (each with triplicate samples). (Upper curves) The correlations between the proportion of events with hypodiploid DNA and the degree of particle release are shown for both apoptotic cell types. The corresponding correlation coefficients, $r$, calculated from linear regression using least squares to fit the data points, were 0.979 for CEM T cells and 0.977 for U-937 cells. 

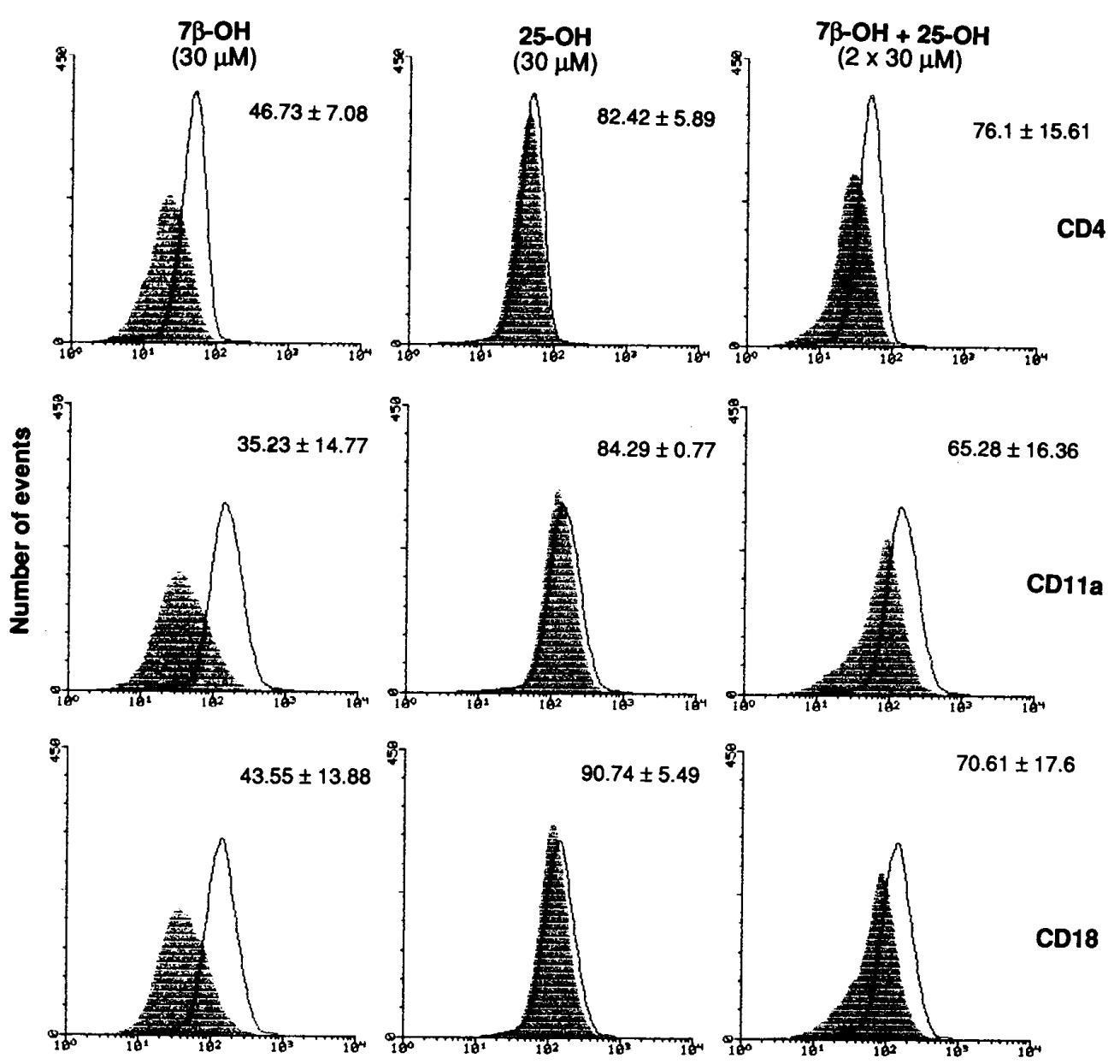

Fluorescence intensity $\left(\log _{10}\right)$

Figure 5. The loss of membrane antigens in U-937 cells undergoing apoptosis after oxysterol treatment. Cells were incubated during $16 \mathrm{~h}$ in the presence of $30 \mu \mathrm{M}$ of either oxysterol, or $2 \times 30 \mu \mathrm{M}$ when combined. Labeling with specific monoclonal antibodies and flow cytometry analysis were then carried out as detailed in Methods. When compared to ethanoltreated, i.e., control cells (empty histograms), oxysterol-treated cells displayed decreased antigen densities (filled histograms). The patterns correspond to a single experiment representative of three performed likewise. Values are mean \pm SD of the percentages of labeled treated cells with respect to corresponding nontreated cells. ture of the agent causing apoptosis. Treatment with $7 \beta-\mathrm{OH}$ induced a fluorescence decay of $\sim 50 \%$ of any of the three antigens while the decay was of the order of $20 \%$ with $25-\mathrm{OH}$. When flow cytometry analyses were performed on saponinpermeabilized cells, identical results were obtained (data not shown). The antigen loss was concomitant with cell shrinkage and was proportional to the degree of apoptosis estimated by hypodiploid DNA (Fig. 1). If it is assumed that antigen loss is related to the release of particles, the latter must carry some of these membrane molecules.

Antigenic characterization of shed membrane particles. In order to identify particle-associated antigens, supernatants were incubated with corresponding insolubilized monoclonal antibodies. Captured particles were revealed through their phosphatidylserine content. Results obtained from control and $7 \beta-\mathrm{OH}$-treated U-937 cells are presented in Table I. The amount of captured particles was dependent on the degree of apoptosis and antigen proportion. Antigen representation was related to that found on cells. Thus $\mathrm{mAb}$ to $\mathrm{CD} 11 \mathrm{a}$ retained more particles than mAb to CD4 which itself bound slightly more particles than control IgG1. Nevertheless, when apoptosis was induced in CEM T cell line, the proportion of retained particles by $\mathrm{mAb}$ to $\mathrm{CD} 4$ was higher than that obtained with apoptotic myeloid cell lines (data not shown). No direct com- parison between capture by annexin $\mathrm{V}$ and $\mathrm{mAb}$ could be done because preincubation times and affinities for the respective ligands are certainly different. However, these experiments establish that particles from supernatant bear a proportion of antigens found on the corresponding cell surfaces.

Table I. The Comparison of the Capture of Shed Particles by Insolubilized Annexin $V$ and Specific $m A$ bs in the Supernatant of Apoptotic U-937 Cells*

\begin{tabular}{lrrrr}
\hline & \multicolumn{4}{c}{ Phosphatidylserine equivalent } \\
\cline { 2 - 5 } & A-V & CD4 & CD11a & Control IgG \\
\hline \multicolumn{5}{c}{$n m$} \\
Ethanol & $0.28 \pm 0.01$ & $0.2 \pm 0.11$ & $0.92 \pm 0.08$ & $0.05 \pm 0.025$ \\
$7 \beta-O H$ & $6.87 \pm 0.32$ & $0.59 \pm 0.08$ & $3.41 \pm 0.22$ & $0.21 \pm 0.05$ \\
& & & & \\
\hline
\end{tabular}

*Cells were treated as described in Fig. 5. The corresponding supernatants were incubated in the presence of insolubilized annexin $\mathrm{V}(A-V)$, anti-CD4, anti-CD-11a, and control IgG1. These values were determined using the prothrombinase assay in which phosphatidylserine is the rate-limiting parameter (Methods). They are the mean \pm SD of three independent experiments (each with triplicate samples). 


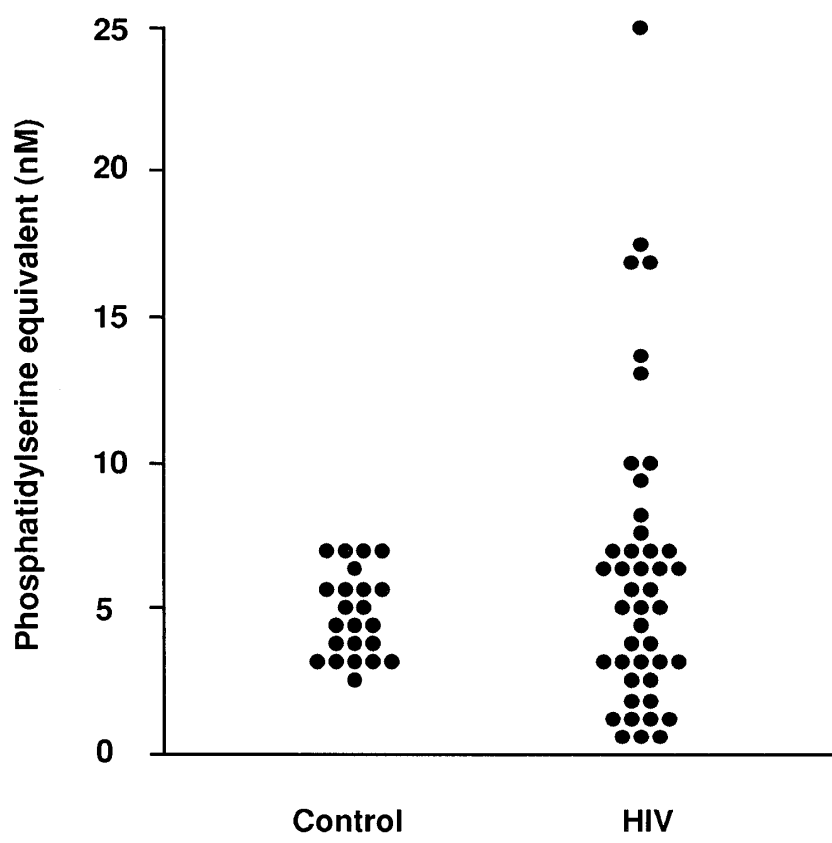

Figure 6. Estimation of the amount of circulating particles in peripheral blood samples from $44 \mathrm{HIV}$-infected individuals and 23 control subjects. The particle capture procedure involving insolubilized annexin V is detailed in Methods as well as the assay of their phosphatidylserine content based on the ability of this phospholipid to promote the assembly of the prothrombinase blood clotting enzyme complex. The mean \pm SD for the control group is $4.72 \pm 1.37 \mathrm{nM}$ phosphatidylserine equivalent, that of the HIV group 6.27 \pm 5.21 , but with a much larger dispersion. Each individual value is the mean of triplicate samples.

Capture and antigenic characterization of circulating particles in blood samples from HIV-infected individuals. Because apoptotic cells are rapidly removed from blood and tissues by phagocytes, the possibility of a longer half-life of derived particles remains an open question, especially under circumstances believed to favor apoptosis. Blood samples from control and $\mathrm{HIV}^{+}$individuals were collected and prepared as described in Methods for the determination of circulating particles. The two groups were sex and age matched as closely as possible. The $\mathrm{HIV}^{+}$subjects constituted an unselected heterogeneous group. The results presented in Fig. 6 show that samples from HIV-infected individuals were more variable with respect to their particle contents than those from control subjects. Some were in the same range as control values, but lower and much higher values were recorded.

To establish the tissue origin of circulating particles, the latter were captured by insolubilized anti-CD4 $\mathrm{mAb}$ and their phosphatidylserine content was estimated using the prothrombinase assay as described in Methods. The results are shown in Fig. 7, together with those of the capture by insolubilized annexin $\mathrm{V}$ and of the tentative capture by immobilized anti$\mathrm{CD} 14 \mathrm{mAb}$. There is a clear evidence that a substantial proportion of particles captured by annexin $\mathrm{V}$ also bore $\mathrm{CD} 4$, whereas anti-CD14 mAb was unable to retain circulating particles. Interestingly, one patient with a circulating $\mathrm{CD}^{+}$particle level of $17.5 \mathrm{nM}$ phosphatidylserine equivalent has been clinically asymptomatic for $>5 \mathrm{yr}$ although his $\mathrm{CD}^{+} \mathrm{T}$ cell count has consistently been below 50 cells $/ \mathrm{mm}^{3}$ during this

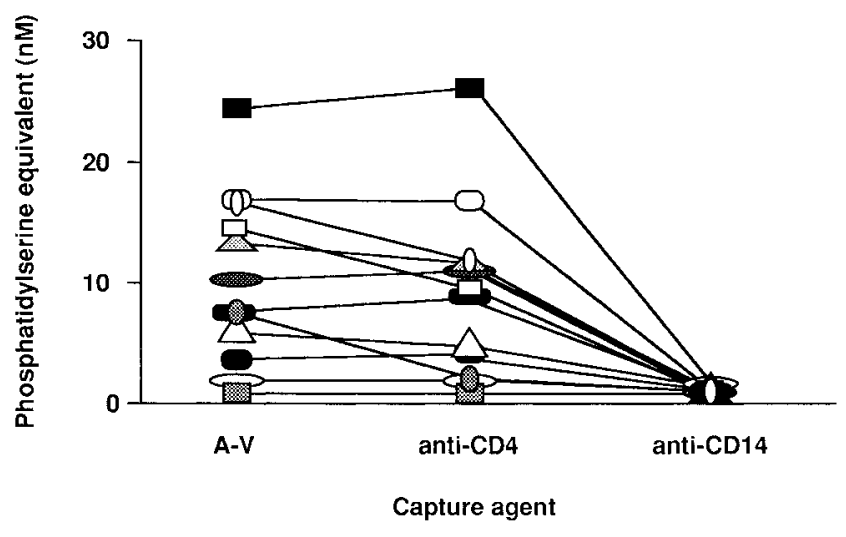

Figure 7. The capture of circulating particles in peripheral blood samples from HIV-infected individuals according to the antigen content. The capture procedure involved insolubilized annexin $\mathrm{V}(A-V)$, $\mathrm{mAbs}$ to $\mathrm{CD} 4$ and $\mathrm{CD} 14$, and irrelevant IgG1, the latter yielding control values $(0.76 \pm 0.35 \mathrm{nM}$ phosphatidylserine equivalent, mean $\pm \mathrm{SD})$ which were subtracted from those reported in this figure. The capture level of the anti-CD14 mAb was precisely of the order of that of control IgG1. The mean \pm SD of the capture level by anti-CD4 in the HIV group is $6.08 \pm 4.96 \mathrm{nM}$ phosphatidylserine equivalent while it is $1.65 \pm 0.57$ in the control group (not shown). See Fig. 6 and Methods for other values and details.

period. Four other patients with $<50 \mathrm{CD} 4^{+} \mathrm{T}$ cells $/ \mathrm{mm}^{3}$ had normal levels of $\mathrm{CD}^{+}$particles and presented a relatively satisfactory clinical status. In control subjects, the levels of circulating $\mathrm{CD}^{+}$particles were about three times lower than those detected after capture by annexin $\mathrm{V}$ but higher than control values obtained with irrelevant IgG1. This observation is suggestive of a certain continuous turnover in the $\mathrm{CD}^{+} \mathrm{T}$ cell population. In samples preincubated with soluble $\mathrm{mAb}$ to $\mathrm{CD} 4$ at only $10 \mu \mathrm{g} / \mathrm{ml}(\sim 60 \mathrm{nM})$, a reduction of anti-CD4-captured particles of $\sim 60 \%$ was noticed in those from three HIVinfected individuals with values ranging between 10 to $16 \mathrm{nM}$ phosphatidylserine equivalent in the absence of soluble antibody. In the pool of plasma samples from control subjects, this reduction was only $25 \%$, but consistent with lower capture levels by insolubilized $\mathrm{mAb}$ to $\mathrm{CD} 4$ than with insolubilized annexin V. No reduction of annexin V-captured particles was noticed with any of these samples preincubated with soluble anti-CD4 mAb.

Preincubation of platelet-free plasma samples in wells coated with insolubilized $\mathrm{mAb}$ to platelet GP Ib resulted in reductions of $\sim 50$ and $90 \%$ of particle capture by insolubilized annexin $\mathrm{V}$ and $\mathrm{GP} \mathrm{Ib}$, respectively, in the pool of samples from control subjects. The reduction was $<10 \%$ in the pool of plasma samples from six $\mathrm{HIV}^{+}$individuals containing an average of $12 \mathrm{nM}$ phosphatidylserine equivalent under normal conditions, i.e., without preincubation with immobilized $\mathrm{mAb}$ to GP Ib.

To exclude any interference from the virus itself in the annexin V-mediated particle capture, the viral load was determined (27) in two $\mathrm{HIV}^{+}$patients with $<50 \mathrm{CD}^{+} \mathrm{T}$ cell $/ \mathrm{mm}^{3}$ and opposing levels of circulating particles at 17.5 and $1.8 \mathrm{nM}$ phosphatidylserine equivalent, respectively. The former presented a moderate viral load of $2 \times 10^{4}$ HIV- 1 RNA molecules $/ \mathrm{ml}$ while this parameter was as high as $3 \times 10^{6}$ molecules/ $\mathrm{ml}$ in the latter. 


\section{Discussion}

The present investigation led to two interesting complementary observations, allowing us to propose another approach of programmed cell death in vivo. The degree of apoptosis is correlated to the amount of particles shed from the membrane of cultured cells in which a death program has been induced. Particles captured in blood samples from HIV-infected individuals have properties comparable to those of their counterparts from cultured cells, and their presence can be related to ongoing apoptosis of a proportion of $\mathrm{CD}^{+} \mathrm{T}$ cells. Phosphatidylserine enabled the capture and estimation of the amount of shed particles. The capture through certain membrane antigens was also feasible, testifying to the tissue origin of the particles.

The correlation between apoptosis and shed membrane particles was demonstrated using four cell lines and six agents able to initiate a cell death program. Among the latter, oxysterols (28) are of particular interest as the effects of $7 \beta-\mathrm{OH}$ and $25-\mathrm{OH}$ with respect to particle and hypodiploid DNA measurements were not additive in U-937 cells whereas they were in HL-60 cells (23). In U-937 cells, the lower values obtained with the combination of $7 \beta-\mathrm{OH}$ and $25-\mathrm{OH}$ than with $7 \beta-\mathrm{OH}$ on its own exclude a nonspecific destabilizing effect of the plasma membrane since in the first case the oxysterol concentration is twice that of the second one. It is of interest to point out that OS, which are hydroxylation products of cholesterol, have been shown to exhibit angiotoxic potential (29) and to induce apoptosis in cultured endothelial cells (30). Furthermore, they could be produced during apoptosis as the result of the associated oxidative burst (31).

The parallel of particle release in the supernatant with the decreased binding of DNA-specific dye to apoptotic cells indicates that there was no lag phase between the two processes, and no difference of sensitivity between the two methods.

The presence of membrane antigens in the shed particles allowed their capture by an insolubilized corresponding antibody. Although, the amount was dependent on the antigen nature and/or representation, their identification is certainly useful for the determination of the cellular origin of the particles when necessary. Antigen loss in cells undergoing apoptosis has already been described by other authors $(32,33)$. Our results are consistent with antigen exportation in free apoptotic particles, and not with internalization or down-regulation of protein expression.

The above results suggest that released particles are reliable markers of apoptosis induced in cultured cells, despite the fact that the underlying mechanisms responsible for phosphatidylserine transverse redistribution in the plasma membrane and particle shedding are not known. It seems relevant to point out that platelet activation is accompanied by the loss of plasma membrane asymmetry and the emission of vesicles bearing exposed phosphatidylserine (34). Another striking parallel between activated platelets and apoptotic cells is the participation of $\mathrm{Ca}^{2+}$-dependent thiol proteases, calpains, in the destabilization of the cytoskeleton $(35,36)$. It could therefore be speculated that the activation of a putative nonspecific lipid scramblase (7) results in phosphatidylserine redistribution between the two leaflets of the plasma membrane. However, there exist at least two cases of natural apparent homozygous disruption of an as yet unidentified gene involved in the transmembrane migration of phosphatidylserine without any evidence of altered apoptosis, referred to as patients with Scott syndrome. Although the platelets, erythrocytes, and lymphocytes from these subjects present the Scott phenotype characterized by a dramatic reduction of phosphatidylserine expression and membrane vesicle shedding following activation, bleeding is the only manifestation $(15,16,37,38)$. For instance, in case of impaired apoptosis, autoimmune disorders directly related to a defect of elimination of auto-reactive lymphocytes should have occurred (1). Furthermore, there was no difference in the calpain-dependent protein cleavage patterns in normal and Scott cells $(16,38)$. Finally, it should be added that a specific phosphatidylcholine membrane transporter has been recently identified as the $m d r 2$ gene $\mathrm{P}$-glycoprotein product (39), while MDR1 P-glycoprotein, which confers multidrug resistance in tumor cells, is a short chain lipid translocase of broad specificity (40).

The demonstration of programmed cell death in vivo is certainly not straightforward (19). Taking advantage of the feasibility of vesicle capture from apoptotic cultured cells, the same high-affinity system was used to assess whether particles with comparable properties would circulate in individuals with disorders susceptible to be related to increased apoptosis. HIV infection is probably one of these situations $(18,19)$ and therefore constitutes a model in humans where dying cells are hardly accessible. In this respect, it is of particular interest to notice that a proportion of circulating particles carry CD4 antigen. This is suggestive of ongoing apoptosis of the sole $\mathrm{CD} 4^{+} \mathrm{T}$ cells since such particles could not be captured through CD14. The observation that individuals with $\mathrm{CD}^{+} \mathrm{T}$ cell count below 50 cells $/ \mathrm{mm}^{3}$ and normal to high proportions of particles are asymptomatic long-term survivors is suggestive of the presence of $\mathrm{CD}^{+} \mathrm{T}$ cells residing in lymphoid tissues, a part of them undergoing apoptosis and the other one achieving normal biological functions. On the other hand, when associated with severe $\mathrm{CD}^{+}{ }^{+} \mathrm{T}$ lymphocytopenia, low particle levels seem to give a very serious prognosis. This could be confirmed by biopsy but only when judged ethical. Another observation, as yet anecdotal, deserving further examination with a larger selective and homogeneous recruitment of $\mathrm{HIV}^{+}$subjects is that of a possible link between a recent loss of $\mathrm{CD}^{+} \mathrm{T}$ cells and an increase of $\mathrm{CD}^{+}{ }^{+}$circulating particles reflecting apoptosis, especially in a context where only $2 \%$ of such cells are normally found in peripheral blood.

When emerging from its host cells, HIV hijacks a higher proportion of phosphatidylserine than of other lipids from their plasma membrane (41) which could be responsible for its capture together with apoptotic particles. However, this is unlikely to happen since there was no correspondence at all between the amount of captured particles and the possible presence of virus in samples from $\mathrm{HIV}$-infected subjects with $\mathrm{CD}^{+} \mathrm{T}$ cell count below 50 cells $/ \mathrm{mm}^{3}$.

Circulating particles in control subjects, are certainly not stemming only from $\mathrm{CD}^{+}{ }^{+} \mathrm{T}$ cells. For instance, we (Hugel, B., T. Vu, G. Socié, M.L. Scrobohaci, J.M. Freyssinet, unpublished results) and other authors (42) have been able to detect platelet (micro)particles. Control experiments with soluble anti-CD4 $\mathrm{mAb}$ and insolubilized $\mathrm{mAb}$ to platelet $\mathrm{GP} \mathrm{Ib}$ enable to assume that in healthy subjects up to $25 \%$ of annexin V-captured membrane particles may stem from $\mathrm{CD}^{+} \mathrm{T}$ cells while up to $50 \%$ may be of platelet origin. Therefore, it seems reasonable to assume that basal levels of circulating particles of various tissue origin reflect a balance between cell proliferation, stimulation, 
and death, in which they transiently escape pure destruction, phagocytosis, and confinement by specific adhesion. Destruction by phospholipases is one of the probable mechanisms, especially by secretory phospholipase A2 which finds its aminophospholipid substrates in shed membrane particles to generate lysophosphatidic acid, a novel lipid proinflammatory mediator (43). Phosphatidylserine-dependent phagocytosis has already been discussed in the introduction. Particles could be involved in the exchange of membrane antigens and biological information when shed from a particular cell type and being involved in an interaction with another cell type through specific adhesion molecules (44).

In individuals presenting disorders suspected to be associated with enhanced rates of programmed cell death, the increase of circulating particles would precisely reflect apoptosis in cells from which they originate. For instance, in addition to HIV infection, we have measured high amounts of circulating particles in blood samples from patients with aplastic anemia (Hugel, B., T. Vu, G. Socié, M.L. Scrobohaci, J.M. Freyssinet, unpublished results), another situation where programmed cell death is thought to occur at a high degree (1). Idiopathic $\mathrm{CD}^{+} \mathrm{T}$ lymphocytopenia (45) would also be worth examining in this respect. In $\mathrm{HIV}^{+}$subjects, the increased susceptibility of PBMCs to apoptosis has been evidenced in cultured isolated cells $(19,46-49)$, and that of $\mathrm{CD}^{+}$and $\mathrm{CD}^{+} \mathrm{T}$ cells by in situ labeling of lymph nodes obtained by biopsy (19). An in vivo sustained emission of membrane fragments bearing accessible phosphatidylserine and having a greater ability to diffuse with respect to cells could explain the occurrence of phosphatidylserine-binding antibodies in HIV-1-infected individuals whose $\mathrm{T}$ cells showed increased in vitro apoptosis (50).

From these in vitro and in vivo observations, we propose that the membrane particles shed from cells undergoing apoptosis can be considered one of the hallmarks of programmed cell death, of particular interest when such cells are hardly accessible. This parameter should prove to be useful for the assessment of the potential of pharmacological agents capable of interfering in programmed cell death.

\section{Acknowledgments}

We express our gratitude to Mrs. Brigitte Schneider for the collection of blood samples, and Mrs. Honey Levallois for correcting the English.

This work was supported by grants from the Institut National de la Santé et de la Recherche Médicale (CRE No. 93-04-06), the Université Louis Pasteur de Strasbourg (EA No. 1313), and the Fondation pour la Recherche Médicale.

\section{References}

1. Thompson, C.B. 1995. Apoptosis in the pathogenesis and treatment of disease. Science (Wash. DC). 267:1456-1462.

2. Majno, G., and I. Joris. 1995. Apoptosis, oncosis, and necrosis: an overview of cell death. Am. J. Pathol. 146:3-15.

3. Martin, S.J., C.P.M. Reutelingsperger, A.J. McGahon, J.A. Rader, R.C.A. van Schie, D.M. LaFace, and D.R. Green. 1995. Early redistribution of plasma membrane phosphatidylserine is a general feature of apoptosis regardless of the initiating stimulus: inhibition by overexpression of Bcl-2 and Abl. $J$. Exp. Med. 182:1545-1556.

4. Devaux, P.F. 1991. Static and dynamic lipid asymmetry in cell membranes. Biochemistry. 30:1163-1173.

5. Allen, T.M., P. Williamson, and R.A. Schlegel. 1988. Phosphatidylserine as a determinant of reticuloendothelial recognition of liposome models of the erythrocyte surface. Proc. Natl. Acad. Sci. USA. 85:8067-8071.
6. Fadok, V.A., D.R. Voelker, P.A. Campbell, J.J. Cohen, D.L. Bratton, and P.M. Henson. 1992. Exposure of phosphatidylserine on the surface of apoptotic lymphocytes triggers specific recognition and removal by macrophages. $J$. Immunol. 148:2207-2216.

7. Verhoven, B., R.A. Schlegel, and P. Williamson. 1995. Mechanisms of phosphatidylserine exposure, a phagocyte recognition signal on apoptotic $\mathrm{T}$ lymphocytes. J. Exp. Med. 182:1597-1601.

8. Luciani, M.F., and G. Chimini. 1996. The ATP binding cassette transporter $\mathrm{ABC1}$, is required for the engulfment of corpses generated by apoptotic cell death. EMBO (Eur. Mol. Biol. Organ.) J. 15:226-235.

9. Ramprasad, M.P., W. Fischer, J.L. Witztum, G.R. Sambrano, O. Quenhenberger, and D. Steinberg. 1995. The 94- to 97-kDa mouse macrophage membrane protein that recognizes oxidized low density lipoprotein and phosphatidylserine rich liposomes is identical to microsialin, the mouse homologue to CD68. Proc. Natl. Acad. Sci. USA. 92:9580-9584.

10. Kornbluth, R.S. 1994. The immunological potential of apoptotic debris produced by tumor cells and during HIV infection. Immunol. Lett. 43:125-132.

11. Casciola-Rosen, L.A., G. Anhalt, and A. Rosen. 1994. Autoantigens targeted in systemic lupus erythematosus are clustered in two populations of surface structures on apoptotic keratinocytes. J. Exp. Med. 179:1317-1330.

12. Casciola-Rosen, L., A. Rosen, M. Petri, and M. Schlissel. 1996. Surface blebs on apoptotic cells are sites of enhanced procoagulant activity: implications for coagulation events and antigenic spread in systemic lupus erythematosus. Proc. Natl. Acad. Sci. USA. 93:1624-1629.

13. Aupeix, K., F. Toti, N. Satta, P. Bischoff, and J.M. Freyssinet. 1996. Oxysterols induce membrane procoagulant activity in monocytic THP-1 cells. Biochem. J. 314:1027-1033.

14. Satta, N., F. Toti, O. Feugeas, A. Bohbot, J. Dachary-Prigent, V. Eschwège, H. Hedman, and J.M. Freyssinet. 1994. Monocyte vesiculation is a possible mechanism for dissemination of membrane-associated procoagulant activities and adhesion molecules after stimulation by lipopolysaccharide. $J$. Immunol. 153:3245-3255.

15. Kojima, H., D. Newton-Nash, H.J. Weiss, J. Zhao, P.J. Sims, and T. Wiedmer. 1994. Production and characterization of transformed B-lymphocytes expressing the membrane defect of Scott syndrome. J. Clin. Invest. 94:22372244.

16. Toti, F., N. Satta, E. Fressinaud, D. Meyer, and J.M. Freyssinet. 1996. Scott syndrome, characterized by impaired transmembrane migration of procoagulant phosphatidylserine and hemorrhagic complications, is an inherited disorder. Blood. 87:1409-1415.

17. Andree, H.A.M., C.P.M. Reutelingsperger, R. Hauptmann, H.C. Hemker, W.Th. Hermens, and G. Willems. 1990. Binding of vascular anticoagulant $\alpha$ (VAC $\alpha)$ to planar phospholipid bilayers. J. Biol. Chem. 265:4923-4928.

18. Ameisen, J.C. 1994. Programmed cell death (apoptosis) and cell survival regulation: relevance to AIDS and cancer. AIDS(Lond.). 8:1197-1213.

19. Finkel, T.H., G. Tudor-Williams, N.K. Banda, M.F. Cotton, T. Curiel, C. Monks, T.W. Baba, R.M. Ruprecht, and A. Kupfer. 1995. Apoptosis occurs predominantly in bystander cells and not in productively infected cells of HIV-and SIV-infected lymph nodes. Nat. Med. 1:129-134.

20. Ravanat, C., J. Torbet, and J.M. Freyssinet. 1992. A neutron solution scattering study of the structure of annexin $\mathrm{V}$ and its binding to lipid vesicles. $J$. Mol. Biol. 226:1271-1278.

21. Pigault, C., A. Follenius-Wund, M. Schmutz, J.M. Freyssinet, and A. Brisson. 1994. Formation of two-dimensional arrays of annexin V on phosphatidylserine-containing liposomes. J. Mol. Biol. 236:199-208.

22. Neuenschwander, P.F., E. Bianco-Fisher, A.R. Rezaie, and J.H. Morrissey. 1995. Phosphatidylethanolamine augments factor VIIa-tissue factor activity: Enhancement of sensitivity to phosphatidylserine. Biochemistry. 34:1398813993.

23. Aupeix, K., D. Weltin, J.E. Mejia, M. Christ, J. Marchal, J.M. Freyssinet, and P. Bischoff. 1995. Oxysterol-induced apoptosis in human monocytic cell lines. Immunobiology. 194:415-428.

24. Larrick, J.W., and S.C. Wright. 1990. Cytotoxic mechanism of tumor necrosis factor- $\alpha$. FASEB J. 4:3215-3223.

25. Dubrez, L., F. Goldwasser, P. Genne, Y. Pommier, and E. Solary. 1995. The role of cell cycle regulation and apoptosis triggering in determining the sensitivity of leukemic cells to topoisomerase I and II inhibitors. Leukemia (Basingstoke). 9:1013-1024.

26. Martin, S.J., S.V. Lennon, A.M. Bonham, and T.G. Cotter. 1990. Induction of apoptosis (programmed cell death) in human leukemic HL-60 cells by inhibition of RNA or protein synthesis. J. Immunol. 145:1859-1867.

27. Mellors, J.W., C.R. Rinaldo, Jr., P. Gupta, R.M. White, J.A. Todd, and L.A. Kingsley. 1996. Prognosis in HIV-1 infection predicted by the quantity of virus in plasma. Science (Wash. DC). 272:1167-1170.

28. Christ, M., B. Luu, J.E. Mejia, I. Moosbrugger, and P. Bischoff. 1993. Apoptosis induced by oxysterols in murine lymphoma cells and in normal thymocytes. Immunology. 78:455-460.

29. Imai, H., N.T. Werthessen, V. Subramanyam, P.W. LeQuesne, A.H. Soloway, and M. Kanisawa. 1980. Angiotoxicity of oxygenated sterols and possible precursors. Science (Wash. DC). 207:651-653.

30. Lizard, G., V. Deckert, L. Dubrez, M. Moisant, P. Gambert, and L. Lagrost. 1996. Induction of apoptosis in endothelial cells treated with cholesterol 
oxides. Am. J. Pathol. 148:1625-1638.

31. Greenspan, H.C., and O.I. Aruoma. 1994. Oxidative stress and apoptosis in HIV infection: a role for plant-derived metabolites with synergistic antioxidant activity. Immunol. Today. 15:209-213.

32. Malorni, W., R. Rivabene, M.T. Santini, S.F. Paradisi, F. Iosi, and G. Donelli. 1993. Down-modulation of CD4 antigen during programmed cell death in U-937 cells. FEBS Lett. 336:335-339.

33. Paramithiotes, E., K.A. Jacobsen, and M.J.H. Ratcliffe. 1995. Loss of surface immunoglobulin expression precedes B cell death by apoptosis in the bursa of Fabricius. J. Exp. Med. 181:127-136.

34. Zwaal, R.F.A., P. Comfurius, and E.M. Bevers. 1993. Mechanisms and function of changes in membrane-phospholipid asymmetry in platelets and erythrocytes. Biochem. Soc. Trans. 21:248-253.

35. Dachary-Prigent, J., J.M. Freyssinet, J.M. Pasquet, J.C. Carron, and A.T. Nurden. 1993. Annexin V as a probe of aminophospholipid exposure and platelet membrane vesiculation: A flow cytometry study showing a role for free sulfhydryl groups. Blood. 81:2554-2565.

36. Martin, S.J., and D.R. Green. 1995. Protease activation during apoptosis: death by a thousand cuts? Cell. 82:349-352.

37. Weiss, H.J. 1994. Scott syndrome: a disorder of platelet coagulant activity. Semin. Hematol 31:312-319.

38. Bevers, E.M., T. Wiedmer, P. Comfurius, S.J. Shattil, H.J. Weiss, R.F.A. Zwaal, and P.J. Sims. 1992. Defective $\mathrm{Ca}^{2+}$-induced microvesiculation and deficient expression of procoagulant activity in erythrocytes from a patient with a bleeding disorder: a study of the red blood cells of Scott syndrome. Blood. 79: 380-388.

39. Smit, J.J.M., A.H. Schinkel, R.P.J. Oude Elfering, A.K. Groen, E. Wagenaar, L. van Deemter, C.C.A.M. Mol, R. Ottenhoff, N.M.T. van der Lugt, M.A. van Roon, et al. 1993. Homozygous disruption of the murine $m d r 2$ P-glycoprotein gene leads to a complete absence of phospholipid from bile and to liver disease. Cell. 75:451-462.

40. Van Helvoort, A., A.J. Smith, H. Sprong, I. Fritzsche, A.H. Schinkel, P. Borst, and G. van Meer. 1996. MDR1 P-glycoprotein is a lipid translocase of broad specificity, while MDR3 P-glycoprotein specifically translocates phosphatidylcholine. Cell. 87:507-517.
41. Aloia, R.C., H. Tian, and F.C. Jensen. 1993. Lipid composition and fluidity of the human immunodeficiency virus envelope and host cell plasma membranes. Proc. Natl. Acad. Sci. USA. 90:5181-5185.

42. Horstman, L.L., W. Jy, D.R. Schultz, W.W. Mao, and Y.S. Ahn. 1994. Complement-mediated fragmentation and lysis of opsonized platelets: gender differences in sensitivity. J. Lab. Clin. Med. 123:515-525.

43. Fourcade, O., M.F. Simon, C. Viodé, N. Rugani, F. Leballe, A. Ragab, B. Fournié, L. Sarda, and H. Chap. 1995. Secretory phospholipase $\mathrm{A}_{2}$ generate the novel lipid mediator lysophosphatidic acid in membrane microvesicles shed from activated cells. Cell. 80:919-927.

44. Tabibzadeh, S.S., Q.F. Kong, and S. Kapur. 1994. Passive acquisition of leukocyte proteins is associated with changes in phosphorylation of cellula proteins and cell-cell adhesion properties. Am. J. Pathol. 145:930-940.

45. Laurence, J., D. Mitra, M. Steiner, D.H. Lynch, F.P. Siegal, and L. Staiano-Colco. 1996. Apoptotic depletion of $\mathrm{CD}^{+}{ }^{+} \mathrm{T}$ cells in idiopathic $\mathrm{CD}^{+}{ }^{+} \mathrm{T}$ lymphocytopenia. J. Clin. Invest. 97:672-680.

46. Groux, H., D. Monte, J.M. Bourrez, A. Capron, and J.C. Ameisen. 1992. Activation-induced death by apoptosis in CD4 T cells from human immunodeficiency virus-infected asymptomatic individuals. J. Exp. Med. 175:331-340.

47. Meyaard, L., S.A. Otto, R.R. Jonker, M.J. Mijnster, R.P.M. Keet, and F. Miedema. 1992. Programmed death of T cells in HIV-1 infection. Science (Wash. DC). 257:217-219.

48. Oyaizu, N., T.W. McCloskey, M. Coronesi, N. Chirmule, V.S. Kalyanaraman, and S. Pahwa. 1993. Accelerated apoptosis in peripheral mononuclear cells (PBMCs) from human immunodeficiency virus type 1-infected patients and in CD4 cross-linked PBMCs from normal individuals. Blood. 82: 3392-3400.

49. Lewis, D.E., D.S. Ng Tang, A. Adu-Oppong, W. Schober, and J.R. Rodgers. 1994. Anergy and apoptosis in $\mathrm{CD}^{+} \mathrm{T}$ cells from HIV-infected persons. J. Immunol. 153:412-420.

50. Silvestris, F., M.A. Frassanito, P. Cafforio, D. Potenza, M. Di Loreto, M Tucci, M.A. Grizzuti, B. Nico, and F. Dammacco. 1996. Antiphosphatidylserine antibodies in human immunodeficiency virus $-1^{+}$patients correlate with evidence of T-cell apoptosis and mediate antibody-dependent cellular cytotoxicity. Blood. 87:5185-5195. 